\title{
Circulating DNA as a Biomarker for Early Detection of Cancer: A Brief Update with an Emphasis on Lung Cancer
}

\author{
Rosa Estela Caseira Cabral, Januario Bispo Cabral Neto* and Maria da Gloria da Costa Carvalho
}

\author{
Universidade Federal do Rio de Janeiro -UFRJ, IBCCF, Av Carlos Chagas Filho, Ilha do Fundão CCS-Bloco G, CEP \\ 21-949-900, RJ, Brazil
}

\begin{abstract}
In most cases, early detection and treatment of cancer are prerequisites for full recovery. However, its early detection continues to be extremely difficult since its characteristic symptoms rarely manifest at the onset of disease. The development of highly sensitive, specific biomarkers also capable of reflecting pathological changes is, therefore, of the upmost importance. Lung cancer, for example, is most frequently diagnosed during the late metastatic stage so that, as a result, malignant neoplasms in the lung are among the leading causes of cancer-related deaths worldwide. Circulating DNA is a non-invasive diagnostic assay that has been greatly improved for the purposes of diagnosis, prognosis, and treatment of cancer. In the current review, we discuss recent data concerning circulating tumor-derived DNA as a tool for early detection, diagnosis, and follow-up. Given the scope of this review, the focus will be on lung cancer, one of the most prolific and lethal cancers affecting humanity today.
\end{abstract}

Keywords: Genetic polymorphism, circulating DNA, lung cancer, risk factor, biomarkers.

\section{INTRODUCTION}

When cells first undergo mutations in key target genes and become cancerous, the symptoms do not typically present for months, or even years, imposing serious difficulties for researchers and clinicians to effectively ensure both early and accurate diagnoses. It is acknowledged that effective cancer therapy is often the result of early detection. For this reason and others, the development of reliable methods primarily utilizing non-invasive biomarkers for early-stage cancer detection is of such overriding importance.

Thanks to Mandel and Metais, the existence of circulating extracellular DNA in the bloodstream was reported as early as 1948 [1]. And the correlation between cell-free nucleic acid levels in plasma and cancer was initially researched in 1977 by Leon et al. [2], who demonstrated for the first time that the plasma levels of free circulating DNA were much higher in cancer patients than in healthy controls.

Nevertheless, the mechanisms by which cell-free DNA is released into the bloodstream remain unknown. It has been suggested that lysis of tumor may be the source of the DNA found in plasma/serum of cancer patients. However, the vast majority of reports in the cell-free DNA field indicate that cell death by apoptosis or necrosis could play a role in this phenomenon. But, although we cannot discard an apoptoticmediated mechanism, we must keep in mind that efficient clearance of apoptotic cells is critical for normal tissue homeostasis, which, in turn, may make it more difficult to explain the liberation of cell-free DNA in the bloodstream of

*Address correspondence to this author at the Universidade Federal do Rio de Janeiro -UFRJ, IBCCF, Av Carlos Chagas Filho, Ilha do Fundão CCSBloco G, CEP 21-949-900, RJ, Brazil; Tel: (55) (21) 2562-6576; Fax: (55) (21) 2280-819; E-mail: cabral@biof.ufrj.br normal individuals due to apoptosis. Contrariwise, the acquisition of apoptotic resistance leading to aberrant cell accumulation is, indeed, an important event in carcinogenesis despite its non-correlation with the hypothesis of apoptotic-mediated, cell-free DNA release in cancer patients.

Concerning necrosis and notwithstanding eventual negative results [3], increased amounts of DNA in the bloodstream of cancer patients with metastasis have been described [4-6]. Even so, after treatment with radiotherapy, assumed to intensify necrosis, the amount of circulating DNA in these patients has been found to remain stable. There are additional data in the literature showing that the circulating DNA in cancer patients mimics cancer-cell DNA. In fact, circulating tumor-derived nucleic acids in cancer patients may harbor tumor-specific genetic alterations and, in this way, could become an interesting target for the noninvasive examination of tumor DNA and ultimately might prove to be a suitable target for the development of diagnosis, prognosis, and follow-up cancer testing [7-12].

\section{FREE CIRCULATING DNA AS A BIOMARKER FOR DETECTING GENETIC ALTERATIONS}

Mutations are heritable changes in DNA, ranging from a single DNA base to a large chromosomal segment. Cancer progression is thought to be driven by the accumulation of a wide spectrum of genetic and epigenetic alterations, including point mutations, chromosomal aberrations, highfrequency microsatellite instability, structural and numerical chromosome abnormalities, and hypermethylation in the promoter region of tumor suppressor genes. The unavoidable rate of endogenous and exogenous DNA damage might account for the accumulation of these abnormalities over several rounds of cell replication. On the other hand, abnormally-elevated levels of genetic instability are mitigated by DNA repair enzymes, responsible for 
preventing unacceptably high mutation rates so as to ensure high-fidelity DNA replication. Elevated levels of genetic instability are also modulated via xenobiotic enzyme activity by catalyzing reactions that lead up to a number of carcinogens. Besides the application of circulating DNA technology in clinical trials based on the amount of cell-free DNA in the bloodstream, its analysis in the plasma/serum of cancer patients allows for the identification of a myriad of inherited, pre-cancerous mutations such as point and epigenetic events affecting the expression of caretaker and gatekeeper genes clearly implicated in the multistep nature of cancer development. In addition, this technology equally identifies microsatellite instability and chromosomal rearrangements. Therefore, it can be reasonably postulated that the concentration of free circulating plasma DNA and the genetic profile of patients suffering from various types of cancerous diseases can be easily investigated by means of a simple, non-invasive blood test, highlighting genetic factors involved in predisposing an individual to cancer. From this perspective, circulating DNA would appear to be an excellent tool for early detection, diagnosis, and follow-up procedures in addition to large-scale prospective clinical trials in high-risk individuals.

\section{ALTERED EPIGENETIC REGULATION ASSESSED BY THE CELL-FREE CIRCULATING DNA TECH- NIQUE}

It is widely agreed that changes in DNA methylation may be involved in numerous cases of cancer. DNA methylation occurs spontaneously in cells as a physiological process, acting as a regulatory mechanism for gene expression. Within the context of the $\mathrm{CpG}$ island, it is possible that DNA methylation is the source of the transcription silencing of genes. It has been demonstrated that DNA methylation in the promoter region of tumor suppressor genes may be the underlying molecular mechanism responsible for this early event in carcinogenesis. Detection of epigenetic DNA methylation is promptly assessed by the circulating DNA technique, thereby opening up the possibility of using the methylated-based analysis of circulating DNA as a tool for early cancer detection [11, 13-18].

Liggett et al. [19] reported a differential methylation status of cell-free circulating DNA among patients with pancreatic cancer and those with inflammatory disease alone. Moreover, a methylation profile of circulating plasma DNA in pancreatic cancer patients was reported by Melnikov et al. These authors found that at least five genes were consistently predictive for plasma-based pancreatic cancer with reasonably high sensitivity and specificity outcomes in the developed composite biomarker [20]. Via a microarray-based technique, they [21] were also able to analyze the differential methylation profile of ovarian cancer tissues and plasma from women belonging to high-risk groups. The results concerning this investigation into cell-free circulating DNA unveiled novel genes that could be informative for cancer detection, suggesting that differential methylation profiling can be achieved in heterogenous samples with reasonable accuracy.

Furthermore, Goessl et al. [22] investigated the GSTP1 promoter hypermethylation in DNA isolated from plasma, serum, semen, and urine taken from the prostate carcinoma tissues of 33 prostate cancer patients and 26 control patients with benign prostatic hyperplasia $(\mathrm{BPH})$. It was found that $94 \%$ of the prostate cancer tissues and $72 \%$ of the plasma and/or serum samples exhibited GSTP1 promoter hypermethylation. Similar lines of evidence were found by Wong et al. [23] when working with tumor-associated, aberrant p16 methylation in the bloodstream of hepatocellular carcinoma patients. In this study, p16 methylation was shown in $73 \%$ of HCC tissues using methylation-specific PCR. Among the 16 cases found to present aberrant methylation in tumor tissues, similar changes were also detected in the plasma/serum samples of $81 \%$. Such studies have indicated a good correlation between restricted expression at the tissue level and the occurrence of detectable levels of candidate biomarkers in serum/plasma DNA. In this connection, the circulating methylated DNA approach has been applied as a biomarker in various forms of cancer, including pancreatic [19, 20, 24, 25], ovarian [2629], prostate carcinoma [30-34], hepatocellular carcinoma [35-38], esophageal adenocarcinoma [39, 40], colorectal carcinoma [8, 41, 42], breast [3, 43-45], head and neck squamous cell carcinoma [46-48], non-Hodgkin lymphoma [49], and lung cancer [10, 16, 18, 50-52].

\section{LOSS OF GENETIC STABILITY DETECTED BY THE CELL-FREE PLASMA/SERUM DNA TECHNIQUE}

It has been well established in the literature that protooncogenes (e.g., ras, EGFR) and tumor suppressor genes (e.g., p53) play a key role in carcinogenesis. Protooncogenes normally control the frequency of cell division. When a proto-oncogene mutates, it becomes a permanentlyactivated oncogene, and, in this capacity, induces successive rounds of cell growth. Tumor suppressor genes have remarkable properties that slow down cell division in response to DNA damage by either triggering apoptosis under certain conditions or by allowing DNA repair processes to take place, both of which are anticarcinogenic processes.

The allele-specific PCR technique has been successfully applied to detected tumor-associated mutations in protooncogene as well as tumor suppressor genes from plasma/serum. Previous research by Salbe et al. [53] has shown that point mutations of the K-ras gene at codon 12 are found in about $40 \%$ of cases with colorectal cancer. In another study, Gormally et al. [54] reported interesting results in a prospective study demonstrating that the TP53 and KRAS2 mutations can be properly detected in plasma DNA of healthy subjects. Their results suggest that the KRAS2 mutation is detectable ahead of a bladder cancer diagnosis and that the TP53 mutation may be associated with environmental exposure. More recently and in the same vein, He et al. [55] reported the detection of epidermal-growthfactor-receptor mutations in plasma by mutant-enriched PCR assay to predict the response to gefitinib in patients with non-small-cell lung cancer, suggesting that this approach has the ability to provide a reliable guidance for clinical decision making in the treatment of advanced NSCLC patients.

\section{CELL-FREE CIRCULATING DNA AS A DIAGNOS- TIC MARKER IN LUNG CANCER}

Lung cancer is a global public health care problem and a leading cause of death in both men and women. Nonetheless, 
effective screening recommendations for early-stage lung cancer detection have not yet been established for any of the high-risk groups, including asymptomatic high-risk populations like older smokers [56-58]. Inherited predisposition to lung cancer can be characterized by a complex genetic trait. Although familial clustering of lung cancer is rare, particular mutations in the genes associated with the clinical responsiveness of lung cancer have been reported. The first known mutation to occur in nonsmoking lung cancer patients was described by Lynch et al. [59]. These authors revealed a significant association between somatic mutations in the tyrosine kinase domain of the epidermal-growth-factor receptor (EGFR) and the responsiveness of non-small-cell lung cancer to gefitinib. Since then, several groups have confirmed these findings [60-66].

Furthering this line of research, many authors have investigated the EGFR pathway genes in lung cancer. Among the oncogenes integrating this pathway, RAS and EGFR itself appear to harbor the most frequently-detected activating mutations reported, with the majority of these mutations being located in non-small-cell lung cancer tumors. In a recent study by Soh et al. [67], the mutational status, copy-number gain, and relative ratio between mutant and wild-type alleles in the EGFR pathway, including KRAS, BRAF, PIK3CA, and EGFR, were also examined. It was found that mutant allele-specific imbalance is frequently present in mutant EGFR and KRAS. These alterations can be correlated with increased mutant-allele transcription and gene activity. Interestingly, with regard to adenocarcinoma lung tumors, all reports have indicated that KRAS mutations and copy-number gains correlated with shortened survival periods.

Thus, it has been well established that EGFR plays a key role in lung cancer therapy. Even so, the role of this oncogene in the development of lung caner remains nebulous. In this regard, the findings reported by $\mathrm{Li}$ and Hemminki [68] may shed some light on this issue in that they describe an inherited predisposition to early-onset lung cancer due to mutations in the EGFR oncogene in a familial clustering with several cases of NSCL. KRAS belonging to the EGFR pathway genes is known to have mutated into various kinds of human tumors. Frequently detected in lung cancer cases [69], almost all mutations in this gene are clustered into three hot spots (namely, codons 12, 13, and 61). Investigations into cancer susceptibility, prevention, risk assessment, management, and therapeutic approaches concerning the KRAS oncogene are currently underway.

Another gene deserving of attention that may possibly be involved with an increased susceptibility to lung cancer is p53. This tumor-suppressor gene is involved in multiple processes implicated in the maintenance of genomic stability, including DNA damage checkpoints, DNA repair, and apoptosis. As a consequence, mutations in p53 have been reported in a wide variety of tumor cells. A lung-cancer risk in germline p53 mutation carriers has been reported by Hwang et al. [70], who also observed that mutation carriers who smoked were significantly more susceptible to the development of lung cancer than their nonsmoking counterparts. In addition to $\mathrm{p} 53$, mutations in $\mathrm{p} 16^{\mathrm{INK} 4 \mathrm{a}}$ have also been investigated as early events and as potential biomarkers for early lung cancer diagnosis [71-74].

Mutations in EGFR, KRAS, P53, and $\mathrm{p} 16^{\mathrm{INK} 4 \mathrm{a}}$, good examples of genes implicated in genomic stability, may actually increase the risk of cancer. Since cell-free circulating DNA does commonly exhibit tumor-related alterations, the detection of abnormalities in caretaker and gatekeeper genes in the bloodstream may be used as a noninvasive DNA-based test for early detection. With regard to lung cancer, multiple articles in recent years have reported a putative association between molecular genetic and epigenetic changes in EGFR pathway genes [75-81], p53 [82], p16 [83-88] and treatment outcomes. Giovannetti et al. [89], have likewise presented interesting results for the prognostic and treatment optimization of NSCLC patients by comparing the connections between EGFR and AKT1 polymorphisms and outcome/toxicity. It was determined that EGFR-activating mutations significantly correlated with response time, longer periods of progression, and overall survival. Conversely, the polymorphic genotype (AKT1SNP4 A/A) seems to be implicated in the primary chemotherapeutic resistance to EGFR tyrosine kinase inhibitors.

Mutations in the KRAS oncogene were also screened by Wang et al. [90] on plasma-extracted DNA and matched tumor tissues of 273 lung cancer patients. It was concluded that the KRAS mutation in plasma DNA correlates with the mutation status of the matched tumor tissues of NSCLC patients and that the plasma KRAS mutation status may be associated with a poor tumor response to EGFR-TKIs in these patients. Altogether, these studies appear to highlight a potential value for cell-free circulating DNA in the early detection, prognosis, and clinical management of lung cancer.

\section{POLYMORPHISMS OF THE XENOBIOTIC-META- BOLIZING GENES DETECTED IN CIRCULATING DNA}

Xenobiotic metabolism occurs through a multistage process involving several detoxification enzymes working in a simultaneous or alternate fashion in classical two- phase steps: phase I, characterized by chemical modifications leading to the creation or release of functional groups; and phase II, in which other functional groups or metabolites are attached to the functional groups originated in phase I. Glutathione S-transferase (GSTs), for example, catalyzes the reaction that attaches glutathione to the xenobiotic compound or its metabolites, thereby promoting the neutralization of their electrophilic center. These events lead to the detoxification of a wide range of carcinogens like the polycyclic aromatic hydrocarbons (PAHs), ethylene oxide, and styrene [91]. Inherited deletion of the GST genes, such as the GSTM1 null polymorphism, is thought to abolish enzymatic activity and, by implication, can be used as a cancer-susceptibility biomarker. Moreover, there is substantial evidence in the literature suggesting that higher levels of polycyclic aromatic hydrocarbon-dGMP adducts are capable of inducing DNA lesions and genomic instabilities in lung tissues. In this connection, our group recently [18] observed a close relationship between smoking status and lung cancer. In this study, the most significant risk 
for tobacco smoking and lung cancer was found in the association of null genotypes for GSTM1 and GSTT1.

\section{CORRECTIONS OF TECHNICAL BIAS IN THE CELL-FREE CIRCULATING NUCLEIC-ACID TECH- NIQUE: ASSESSMENT OF LIMITATIONS AND POTENTIAL IMPROVEMENTS}

The utilization of cell-free circulating nucleic acids has been introduced as an easy-to-use, non-invasive technique for cancer diagnosis. In addition to being valuable sources of biomarkers, nucleic acids are biomarkers themselves. As such, they can effectively be used as tools for early detection, diagnosis, and follow-up of the disease. Their major technical challenge, however, is the limitation exerted by the low quantity and poor quality of tumor-specific DNA and its contamination by normal DNA. To overcome these shortcomings, some published articles have focused on the development of alternative protocols.

It is assumed that human blood contains a pool of tumorspecific DNA derived from focal areas of a heterogeneous primary tumor containing diverse genetic abnormalities, If true, plasma DNA would probably be an appropriate source for detecting the loss of heterozygosity (LOH) [92]. Detection of LOH in cell-free circulating DNA may be constrained by the restrictions mentioned above. Muller et al. [93] have attempted to overcome this dilemma by taking advantage of a PCR-based fluorescence microsatellite assay for 12 polymorphic markers for the purpose of investigating $\mathrm{LOH}$ in the cell-free plasma DNA of 59 prostate cancer patients. To enrich the DNA portion containing shorter fragments [94], fractionation of plasma DNA into high and low molecular weights was performed. To enhance assay sensitivity for $\mathrm{LOH}$ detection in circulating DNA and avoid artificial discoveries, the authors proposed increasing the yield and specificity of PCR by adding tetramethlammonium chloride to each PCR reaction. In an effort to improve assay sensitivity for quantitative analysis of DNA methylation in circulating DNA, on the other hand, Vaissiere et al. [95] proposed a novel combination of methods based on genome-wide amplification of bissulphite-modified DNA template followed by quantitative methylation detection using pyrosequencing. These authors successfully analyzed multiple genes from a small amount of starting DNA. Furthermore, there is evidence in the literature suggesting that the integrity of serum-circulating DNA may play a biomarker role in detecting cancer-tumor progression and regional metastasis [6]. In order to improve analyzing the size of circulating DNA and quantifying circulating nucleic-acid fragments in human serum, Liu et al. [96], have developed a PCR-free, single-molecule assay for CAN analysis based on microfluidic, cylindrical illumination, confocal spectroscopy. Thus, the authors have put forward an alternative method, which, if accompanied by an appropriate assay design and probe specificity, may be able to accurately analyze DNA integrity in cell-free circulating DNA.

\section{CIRCULATING DNA VERSUS CIRCULATING TUMOR CELLS TECHNIQUE}

In addition to cell free-circulating DNA, detection and quantification of circulating cancer cells in peripheral blood may also improve cancer staging and monitoring. We have already outlined in a previous paragraph specific concerns that are relevant for accurate detection of cell-free tumor DNA in the blood of cancer patients harboring tumor- specific aberration. In the case of circulating tumor cells (CTCs) from blood specimens of patients with cancer the major technical challenge we have to face to detect a very selected few CTCs among so many leukocytes, erythrocytes and epithelial non-tumor cells which are also supposed to be found in blood stream. In this context, when non-tumor cells are inappropriately detected as real circulating tumor cells It can have strong negative therapeutic effects. Nonetheless, technical advances have facilitated the detection of rare circulating tumor cells in the bloodstream. Gabri et al. [97], for instance, reported interesting results in an experimental study designed to evaluate molecular detection of circulating melanoma cells by reverse transcription-polymerase chain reaction (RT-PCR). Their results suggest that very small amounts of tyrosinase mRNA which is an enzyme specifically expressed by melanocytes and melanoma cells can be properly detected through nested PCR needing an amount of total RNA comparable to less than a single melanoma cell. More recently, Katz et al. [98] proposed a novel methodology to detect circulating abnormal cells in peripheral blood of patients with NSCLC. In an attempt to improve assay sensitivity for quantitative analysis of circulating genetically abnormal cells (CACs) they have developed a technique to determine if a fluorescence in situ hybridization (FISH)-based assay using isolated peripheral blood mononuclear cells with DNA probes targeting specific sites on chromosomes known to have abnormalities in nonsmall cell lung cancer cases could detect circulating genetically abnormal cells. These authors successfully achieved a significant correlation between the numbers of CACs and the presence of cancer. In order to improve efficient detection of tumor cells from peripheral blood of patients with cancer, Hosokawa et al. [99] have developed a microfluidic device equipped with a size-selective microcavity array which can specifically separate tumor cells from in the bloodstream on the basis of differences in the size and deformability between tumor and hematologic cells. The cells recovered on the microcavity array were further processed for image-based immunophenotypic analysis using a fluorescence microscope. These authors successfully recovered lung carcinoma, breast, gastric and colon tumor cells on the microcavity array with high efficiency, suggesting that their microfluidic technique has some potential as a tool for the detection of circulating tumor cells.

\section{CONCLUSIONS}

Lung cancer is one of the most frequently-diagnosed cancers worldwide. Lung cancer cells undergo metastasis very soon after carcinogenesis, characterizing the lung neoplasm as a particularly dangerous, life-threatening cancer. Free circulating DNA has been used as a noninvasive source of biomarker candidates, having been deemed particularly useful in cancer staging, prognosis, and treatment selection. Our knowledge regarding the molecular features of lung malignancies, and the ability to accurately measure an abnormal amount of free circulating DNA has the potential to greatly advance our current skill levels in making the clinical management of the disease more efficient. Despite remarkable progress in this type of research, however, many controversial results and technical challenges continue to afflict professionals in the field. Consequently, there is no doubt that the development of 
either a specific single- or multiple-step diagnostic procedure is urgently needed.

\section{ACKNOWLEDGEMENTS}

This work was supported by FAPERJ (Rio de Janeiro, RJ, Brazil), CNPq (Brasilia, DF, Brazil) together with the Fundação do Câncer/Oncobiologia and was edited by Judy Grevan.

\section{ABREVIATIONS}

$\begin{array}{ll}\text { NSCLC } & =\text { Non-small-cell lung cancer } \\ \text { EGFR } & =\text { Epidermal growth factor receptor } \\ \text { EGFR TKIs } & =\begin{array}{l}\text { Epidermal growth factor receptor } \\ \text { tyrosine kinase inhibitors }\end{array} \\ \text { HCC } & =\text { Hepatocellular carcinoma } \\ \text { LC } & =\text { Lung cancer } \\ \text { CAN } & =\text { Circulating nucleic acid } \\ \text { CTCs } & =\text { Circulating tumor cells }\end{array}$

\section{REFERENCES}

[1] Mandel P, Metais P. Les acides nucleiques du plasma sanguin chez l'homme. C R Acad Sci Paris 1948; 142: 241-3.

[2] Leon SA, Shapiro B, Sklaroff DM, Yaros MJ. Free DNA in the serum of cancer patients and the effect of therapy. Cancer Res 1977; 37: 646-50.

[3] Kohler C, Radpour R, Barekati Z, et al. Levels of plasma circulating cell free nuclear and mitochondrial DNA as potential biomarkers for breast tumors. Mol Cancer 2009; 8: 105.

[4] Zhong XY, Ladewig A, Schmid S, Wight E, Hahn S, Holzgreve W. Elevated level of cell-free plasma DNA is associated with breast cancer. Arch Gynecol Obstet 2007; 276: 327-31.

[5] Frattini M, Gallino G, Signoroni S et al. Quantitative analysis of plasma DNA in colorectal cancer patients: a novel prognostic tool. Ann N Y Acad Sci 2006; 1075: 185-90.

[6] Umetani N, Giuliano AE, Hiramatsu SH, et al. Prediction of breast tumor progression by integrity of free circulating DNA in serum. J Clin Oncol 2006; 24: 4270-6.

[7] Fleischhacker M, Schmidt B. Cell-free DNA resuscitated for tumor testing. Nat Med 2008; 14: 914-5.

[8] Garcia-Olmo DC, Dominguez C, Garcia-Arranz M, et al. Cell-free nucleic acids circulating in the plasma of colorectal cancer patients induce the oncogenic transformation of susceptible cultured cells. Cancer Res 2010; 70: 560-7.

[9] Kamat AA, Baldwin M, Urbauer D, et al. Plasma cell-free DNA in ovarian cancer: an independent prognostic biomarker. Cancer 2010; 116: 1918-25.

[10] Kumar S, Guleria R, Singh V, Bharti AC, Mohan A, Das BC. Plasma DNA level in predicting therapeutic efficacy in advanced non-small cell lung cancer. Eur Respir J 2010; [Epub ahead of print].

[11] Liggett T, Melnikov A, Yi QL, et al. Differential methylation of cell-free circulating DNA among patients with pancreatic cancer versus chronic pancreatitis. Cancer 2010; 116: 1674-80.

[12] Vlassov VV, Laktionov PP, Rykova EY. Circulating nucleic acids as a potential source for cancer biomarkers. Curr Mol Med 2010; 10: $142-65$.

[13] Chen Z., Fan JQ, Li J, et al. Promoter hypermethylation correlates with the Hsulf-1 silencing in human breast and gastric cancer. Int $\mathbf{J}$ Cancer 2009; 124: 739-44.

[14] Ellinger J, Albers P, Perabo FG, Muller SC, von Ruecker A, Bastian PJ. CpG island hypermethylation of cell-free circulating serum DNA in patients with testicular cancer. J Urol 2009; 182: 324-9.

[15] Hoffmann AC, Vallbohmer D, Prenzel K, et al. Methylated DAPK and APC promoter DNA detection in peripheral blood is significantly associated with apparent residual tumor and outcome. J Cancer Res Clin Oncol 2009; 135: 1231-7.
[16] Pan SY, Xie EF, Shu YQ, et al. Methylation quantification of adenomatous polyposis coli (APC) gene promoter in plasma of lung cancer patients. Ai Zheng 2009; 28: 384-9.

[17] Rykova EY, Tsvetovskaya GA, Sergeeva GI, Vlassov VV, Laktionov PP. Methylation-based analysis of circulating DNA for breast tumor screening. Ann N Y Acad Sci 2008; 1137: 232-5.

[18] Cabral RE, Caldeira-de-Araujo A, Cabral-Neto JB, Costa Carvalho MD. Analysis of GSTM1 and GSTT1 polymorphisms in circulating plasma DNA of lung cancer patients. Mol Cell Biochem 2010; 338: 263-9.

[19] Liggett T, Melnikov A, Yi QL. Differential methylation of cell-free circulating DNA among patients with pancreatic cancer versus chronic pancreatitis. Cancer 2010; 116: 1674-80.

[20] Melnikov AA, Scholtens D, Talamonti MS, Bentrem DJ, Levenson VV. Methylation profile of circulating plasma DNA in patients with pancreatic cancer. J Surg Oncol 2009; 99: 119-22.

[21] Melnikov A, Scholtens D, Godwin A, Levenson V. Differential methylation profile of ovarian cancer in tissues and plasma. J Mol Diagn 2009; 11: 60-5.

[22] Goessl C, Krause H, Muller M, et al. Fluorescent methylationspecific polymerase chain reaction for DNA-based detection of prostate cancer in bodily fluids. Cancer Res 2000; 60: 5941-5.

[23] Wong IH, Lo YM, Zhang J, et al. Detection of aberrant p16 methylation in the plasma and serum of liver cancer patients. Cancer Res 1999; 59: 71-3.

[24] Bagul A, Pushpakom S, Boylan J, Newman W, Siriwardena AK. Quantitative analysis of plasma DNA in severe acute pancreatitis. JOP 2006; 7: 602-7.

[25] Marchese R, Muleti A, Pasqualetti P, et al. Low correspondence between K-ras mutations in pancreatic cancer tissue and detection of K-ras mutations in circulating DNA. Pancreas 2006; 32: 171-7.

[26] Kamat AA, Bischoff FZ, Dang D, et al. Circulating cell-free DNA: a novel biomarker for response to therapy in ovarian carcinoma. Cancer Biol Ther 2006; 5: 1369-74.

[27] Kamat AA, Sood AK, Dang D, Gershenson DM, Simpson JL, Bischoff FZ. Quantification of total plasma cell-free DNA in ovarian cancer using real-time PCR, Ann N Y Acad Sci 2006; 1075: 230-4.

[28] Ma L, Liu FR, Zhang SL. Detection of circulating hypermethylated tumor-specific RASSF1A DNA in ovarian cancer patients. Zhonghua Bing Li Xue Za Zhi 2005; 34: 785-7.

[29] Zachariah RR, Schmid S, Buerki N, Radpour R, Holzgreve W, Zhong X. Levels of circulating cell-free nuclear and mitochondrial DNA in benign and malignant ovarian tumors. Obstet Gynecol 2008; 112: 843-50.

[30] Bryzgunova OE, Morozkin ES, Yarmoschuk SV, Vlassov VV, Laktionov PP. Methylation-specific sequencing of GSTP1 gene promoter in circulating/extracellular DNA from blood and urine of healthy donors and prostate cancer patients. Ann N Y Acad Sci 2008; 1137: 222-5.

[31] Cherepanova AV, Tamkovich SN, Bryzgunova OE, Vlassov VV, Laktionov PP. Deoxyribonuclease activity and circulating DNA concentration in blood plasma of patients with prostate tumors. Ann N Y Acad Sci 2008; 1137: 218-21.

[32] Okegawa T, Nutahara K, Higashihara E. Association of circulating tumor cells with tumor-related methylated DNA in patients with hormone-refractory prostate cancer. Int J Urol 2010; 17: 466-75.

[33] Schwarzenbach H, Alix-Panabieres C, Muller I, et al. Cell-free tumor DNA in blood plasma as a marker for circulating tumor cells in prostate cancer. Clin Cancer Res 2009; 15: 1032-8.

[34] Sunami E, Shinozaki M, Higano CS, et al. Multimarker circulating DNA assay for assessing blood of prostate cancer patients. Clin Chem 2009; 55: 559-67.

[35] Chan KC, Lai PB, Mok TS, et al. Quantitative analysis of circulating methylated DNA as a biomarker for hepatocellular carcinoma. Clin Chem 2008; 54: 1528-36.

[36] Iida M, Iizuka N, Sakaida I, et al. Relation between serum levels of cell-free DNA and inflammation status in hepatitis $C$ virus-related hepatocellular carcinoma. Oncol Rep 2008; 20: 761-5.

[37] Pang JZ, Qin LX, Wang QQ, et al. Loss of heterozygosity of plasma circulating DNA from hepatocellular carcinoma patients and its clinical significance. Zhonghua Gan Zang Bing Za Zhi 2007; 15: 906-9.

[38] Tokuhisa Y, Iizuka N, Sakaida I, et al. Circulating cell-free DNA as a predictive marker for distant metastasis of hepatitis $\mathrm{C}$ virusrelated hepatocellular carcinoma. Br J Cancer 2007; 97: 1399-403. 
[39] Eisenberger CF, Stoecklein NH, Jazra S, et al. The detection of oesophageal adenocarcinoma by serum microsatellite analysis. Eur J Surg Oncol 2006; 32: 954-60.

[40] Jin Z, Olaru A, Yang J, et al. Hypermethylation of tachykinin-1 is a potential biomarker in human esophageal cancer. Clin Cancer Res 2007; 13: 6293-300.

[41] Schwarzenbach H, Goekkurt E, Pantel K., Aust DE, Stoehlmacher J. Molecular analysis of the polymorphisms of thymidylate synthase on cell-free circulating DNA in blood of patients with advanced colorectal carcinoma. Int J Cancer 2010; 127(4): 881-8.

[42] Schwarzenbach H, Stoehlmacher J, Pantel K, Goekkurt E. Detection and monitoring of cell-free DNA in blood of patients with colorectal cancer. Ann N Y Acad Sci 2008; 1137: 190-6.

[43] Board RE, Wardley AM, Dixon JM, et al. Detection of PIK3CA mutations in circulating free DNA in patients with breast cancer. Breast Cancer Res Treat 2010; 120: 461-7.

[44] Mirza S, Sharma G, Parshad R, Srivastava A, Gupta SD, Ralhan R. Clinical significance of Stratifin, ERalpha and PR promoter methylation in tumor and serum DNA in Indian breast cancer patients. Clin Biochem 2010; 43: 380-6.

[45] Nunes RA, Li X, Kang SP, et al. Circulating tumor cells in HER-2 positive metastatic breast cancer patients treated with trastuzumab and chemotherapy. Int J Biol Markers 2009; 24: 1-10.

[46] Jiang WW, Zahurak M, Goldenberg D, et al. Increased plasma DNA integrity index in head and neck cancer patients. Int J Cancer 2006; 119: 2673-6.

[47] Nawroz-Danish H, Eisenberger CF, Yoo GH, et al. Microsatellite analysis of serum DNA in patients with head and neck cancer. Int J Cancer 2004; 111: 96-100.

[48] Yu KH, Lo YM, Tse GM, et al. Quantitative analysis of cell-free Epstein-Barr virus DNA in plasma of patients with nonnasopharyngeal head and neck carcinomas. Clin Cancer Res 2004; 10: 1726-32.

[49] Hosny G, Farahat N, Hainaut P. TP53 mutations in circulating free DNA from Egyptian patients with non-Hodgkin's lymphoma. Cancer Lett 2009; 275: 234-9.

[50] Kumar S, Guleria R, Singh V, Bharti AC, Mohan A, Das BC. Efficacy of circulating plasma DNA as a diagnostic tool for advanced non-small cell lung cancer and its predictive utility for survival and response to chemotherapy. Lung Cancer 2010. [Epub ahead of print]

[51] Takai D. Aberrant methylation of circulating DNA for prediction of chemo-sensitivity of non-small cell lung cancer. Gan To Kagaku Ryoho 2010; 37: 189-93.

[52] van der Drift MA, Hol BE, Klaassen CH. Circulating DNA is a non-invasive prognostic factor for survival in non-small cell lung cancer. Lung Cancer 2010; 68: 283-7.

[53] Salbe C, Trevisiol C, Ferruzzi E. Molecular detection of codon 12 K-RAS mutations in circulating DNA from serum of colorectal cancer patients. Int J Biol Markers 2000; 15: 300-7.

[54] Gormally E, Vineis P, Matullo G, et al. TP53 and KRAS2 mutations in plasma DNA of healthy subjects and subsequent cancer occurrence: a prospective study. Cancer Res 2006; 66: 6871-6.

[55] He C, Liu M, Zhou C, et al. Detection of epidermal growth factor receptor mutations in plasma by mutant-enriched PCR assay for prediction of the response to gefitinib in patients with non-smallcell lung cancer. Int J Cancer 2009; 125: 2393-9.

[56] Dash B, Afriyie-Gyawu E, Huebner HJ, et al. Noninvasive identification of interindividual variation in xenobioticmetabolizing enzymes: implications for cancer epidemiology and biomarker studies. J Toxicol Environ Health 2006; 69: 1203-16.

[57] Thier R, Bruning $\mathrm{T}$, Roos $\mathrm{PH}$, et al. Markers of genetic susceptibility in human environmental hygiene and toxicology: the role of selected CYP, NAT and GST genes. Int J Hyg Environ Health 2003; 206: 149-71.

[58] Wang S, Chanock S, Tang D, Li Z, Jedrychowski W, Perera FP. Assessment of interactions between $\mathrm{PAH}$ exposure and genetic polymorphisms on PAH-DNA adducts in African American, Dominican, and Caucasian mothers and newborns. Cancer Epidemiol Biomarkers Prev 2008; 17: 405-13.

[59] Lynch TJ, Bell DW, Sordella R, et al. Activating mutations in the epidermal growth factor receptor underlying responsiveness of non-small-cell lung cancer to gefitinib. N Engl J Med 2004; 350: 2129-39.
[60] Carmi C, Cavazzoni A, Vezzosi S, et al. Novel irreversible epidermal growth factor receptor inhibitors by chemical modulation of the cysteine-trap portion. J Med Chem 2010; 53: 2038-50.

[61] Ercan D, Zejnullahu K, Yonesaka K, et al. Amplification of EGFR T790M causes resistance to an irreversible EGFR inhibitor. Oncogene 2010; 29: 2346-56.

[62] Galetti M, Alfieri RR, Cavazzoni A, et al. Functional characterization of gefitinib uptake in non-small cell lung cancer cell lines. Biochem Pharmacol 2010; 80: 179-87.

[63] Gandhi J, Zhang J, Xie Y, et al. Alterations in genes of the EGFR signaling pathway and their relationship to EGFR tyrosine kinase inhibitor sensitivity in lung cancer cell lines. PLoS One 2009; 4: e4576.

[64] Ozaki K, Kosugi M, Baba N, et al. Blockade of the ERK or PI3KAkt signaling pathway enhances the cytotoxicity of histone deacetylase inhibitors in tumor cells resistant to gefitinib or imatinib. Biochem Biophys Res Commun 2010; 391: 1610-5.

[65] Provencio M, Sanchez A, Garrido P, Valcarcel F. New molecular targeted therapies integrated with radiation therapy in lung cancer. Clin Lung Cancer 2010; 11: 91-7.

[66] Zhong M, Ma X, Sun C, Chen L. MicroRNAs reduce tumor growth and contribute to enhance cytotoxicity induced by gefitinib in nonsmall cell lung cancer. Chem Biol Interact 2010; 184: 431-8.

[67] Soh J, Okumura N, Lockwood WW, et al. Oncogene mutations, copy number gains and mutant allele specific imbalance (MASI) frequently occur together in tumor cells. PLoS One 2009; 4: e7464.

[68] Li X, Hemminki K. Inherited predisposition to early onset lung cancer according to histological type. Int J Cancer 2004; 112: 4517.

[69] Minamoto T, Mai M, Ronai Z. K-ras mutation: early detection in molecular diagnosis and risk assessment of colorectal, pancreas, and lung cancers--a review. Cancer Detect Prev 2000; 24: 1-12.

[70] Hwang SJ, Cheng LS, Lozano G, Amos CI, Gu X, Strong LC. Lung cancer risk in germline p53 mutation carriers: association between an inherited cancer predisposition, cigarette smoking, and cancer risk. Hum Genet 2003; 113: 238-43.

[71] Panani AD, Maliaga K, Babanaraki A, Bellenis I. Numerical abnormalities of chromosome 9 and p16CDKN2A gene deletion detected by FISH in non-small cell lung cancer. Anticancer Res 2009; 29: 4483-7.

[72] Peng Z, Shan C, Wang H. Value of promoter methylation of RASSF1A, p16, and DAPK genes in induced sputum in diagnosing lung cancers. Zhong Nan Da Xue Xue Bao Yi Xue Ban 2010; 35: 247-53.

[73] Ye Y, Wang D, Su C, Rong T, Guo A. Combined detection of p53, $\mathrm{p} 16, \mathrm{Rb}$, and EGFR mutations in lung cancer by suspension microarray. Genet Mol Res 2009; 8: 1509-18.

[74] Okamoto A, Hussain SP, Hagiwara K, et al. Mutations in the p16INK4/MTS1/CDKN2, p15INK4B/MTS2, and p18 genes in primary and metastatic lung cancer. Cancer Res 1995; 55: 1448-51.

[75] Gautschi O, Huegli B, Ziegler A, et al. Origin and prognostic value of circulating KRAS mutations in lung cancer patients. Cancer Lett 2007; 254: 265-73.

[76] Jian G, Songwen Z, Ling Z, et al. Prediction of epidermal growth factor receptor mutations in the plasma/pleural effusion to efficacy of gefitinib treatment in advanced non-small cell lung cancer. J Cancer Res Clin Oncol 2010; 136(9): 1341-7.

[77] Kimura H, Kasahara K, Kawaishi M, et al. Detection of epidermal growth factor receptor mutations in serum as a predictor of the response to gefitinib in patients with non-small-cell lung cancer. Clin Cancer Res 2006; 12: 3915-21.

[78] Kimura H, Suminoe M, Kasahara K, et al. Evaluation of epidermal growth factor receptor mutation status in serum DNA as a predictor of response to gefitinib (IRESSA). Br J Cancer 2007; 97: 778-84.

[79] Kuang Y, Rogers A, Yeap BY, et al. Noninvasive detection of EGFR T790M in gefitinib or erlotinib resistant non-small cell lung cancer. Clin Cancer Res 2009; 15: 2630-6.

[80] Magistrelli P, Neri M, Granone P, Cesario A, Paleari L, Russo P. K-ras mutations in circulating DNA from pancreatic and lung cancers: bridging methodology for a common validation of the molecular diagnosis value. Pancreas 2008; 37: 101-2.

[81] Maheswaran S, Sequist LV, Nagrath S, et al. Detection of mutations in EGFR in circulating lung-cancer cells. N Engl J Med 2008; 359: 366-77. 
[82] Ludovini V, Pistola L, Gregorc V, et al. Plasma DNA, microsatellite alterations, and $\mathrm{p} 53$ tumor mutations are associated with disease-free survival in radically resected non-small cell lung cancer patients: a study of the perugia multidisciplinary team for thoracic oncology. J Thorac Oncol 2008; 3: 365-73.

[83] An Q, Liu Y, Gao Y, et al. Detection of p16 hypermethylation in circulating plasma DNA of non-small cell lung cancer patients. Cancer Lett 2002; 188: 109-14.

[84] Bearzatto A, Conte D, Frattini M, et al. p16(INK4A) Hypermethylation detected by fluorescent methylation-specific PCR in plasmas from non-small cell lung cancer. Clin Cancer Res 2002; 8: 3782-7.

[85] Belinsky SA, Klinge DM, Dekker JD, et al. Gene promoter methylation in plasma and sputum increases with lung cancer risk. Clin Cancer Res 2005; 11: 6505-11.

[86] Liu Y, An Q, Li L, et al. Hypermethylation of p16INK4a in Chinese lung cancer patients: biological and clinical implications. Carcinogenesis 2003; 24: 1897-901.

[87] Ng CS, Zhang J, Wan S, et al. Tumor p16M is a possible marker of advanced stage in non-small cell lung cancer. J Surg Oncol 2002; 79: 101-6.

[88] Ramirez JL, Taron M, Balana C, et al. Serum DNA as a tool for cancer patient management. Rocz Akad Med Bialymst 2003; 48: $34-41$.

[89] Giovannetti E, Zucali PA, Peters GJ, et al. Association of polymorphisms in AKT1 and EGFR with clinical outcome and toxicity in non-small cell lung cancer patients treated with gefitinib. Mol Cancer Ther 2010; 9: 581-93.

[90] Wang S, An T, Wang J, et al. Potential clinical significance of a plasma-based KRAS mutation analysis in patients with advanced non-small cell lung cancer. Clin Cancer Res 2010; 16: 1324-30.

[91] Antolino Lobo I, Meulenbelt J, Nijmeijer SM, Scherpenisse P, van den Berg M, van Duursen MB. Differential roles of phase I and phase II enzymes in 3,4-methylendioxymethamphetamine (MDMA)-induced cytotoxicity. Drug Metab Dispos 2010; 38(7): 1105-12.

[92] Bonkhoff H, Remberger K. Morphogenetic concepts of normal and abnormal growth in the human prostate. Virchows Arch 1998; 433: 195-202.

[93] Muller I, Beeger C, Alix-Panabieres C, Rebillard X, Pantel K, Schwarzenbach H. Identification of loss of heterozygosity on circulating free DNA in peripheral blood of prostate cancer patients: potential and technical improvements. Clin Chem 2008; 54: 688-96.

[94] Wang M, Block TM, Steel L, Brenner DE, Su YH. Preferential isolation of fragmented DNA enhances the detection of circulating mutated k-ras DNA. Clin Chem 2004; 50: 211-3.

[95] Vaissiere T, Cuenin C, Paliwal A. Quantitative analysis of DNA methylation after whole bisulfitome amplification of a minute amount of DNA from body fluids. Epigenetics 2009; 4: 221-30.

[96] Liu KJ, Brock MV, Shih Ie M, Wang TH. Decoding circulating nucleic acids in human serum using microfluidic single molecule spectroscopy. J Am Chem Soc 2010; 132: 5793-8.

[97] Gabri MR, Vazquez V, Girón S, et al. Molecular detection of circulating tyrosinase mRNA: Optimization in a preclinical xenograft mouse melanoma model and further evaluation in samples from advanced melanoma patients. Int J Mol Med 2008; 21(5): 555-9.

[98] Katz RL, He W, Khanna A, et al. Genetically abnormal circulating cells in lung cancer patients: an antigen-independent fluorescence in situ hybridization-based case-control study. Clin Cancer Res 2010; 16(15): 3976-87.

[99] Hosokawa M, Hayata T, Fukuda Y, et al. Size-selective microcavity array for rapid and efficient detection of circulating tumor cells. Anal Chem 2010; 82(15): 6629-35.

(C) Cabral et al.; Licensee Bentham Open.

This is an open access article licensed under the terms of the Creative Commons Attribution Non-Commercial License (http://creativecommons.org/licenses/by-nc/ 3.0/) which permits unrestricted, non-commercial use, distribution and reproduction in any medium, provided the work is properly cited 